\title{
Adventitious blindness: The road to self-acceptance
}

Catama, Bryan V.

Saint Louis University, Philippines (chapsbryan12@gmail.com)

Del Castillo, Alayla Louise A.

Saint Louis University, Philippines (Delcastilloal98@gmail.com)

Espino, Athena Grace S.

Saint Louis University, Philippines (athenagraceespino@gmail.com)

Beleo, Melanie K.

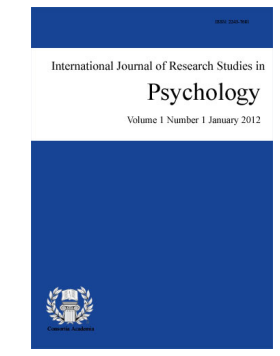

ISSN: 2243-7681 Online ISSN: 2243-769X

OPEN ACCESS

Saint Louis University, Philippines (lanie08ellay@gmail.com)

Blanca, Leda Mae V.

Saint Louis University, Philippines (Ledavbblanca@gmail.com)

Bunagan, Moira Angela B.

Saint Louis University, Philippines (moiraangelagrace@gmail.com)

Cruz, Eliel Dhenise M.

Saint Louis University, Philippines (dhenise1120@gmail.com)

\section{Abstract}

Self-acceptance is the very foundation of one's identity before developing other areas of personal well-being. People with adventitious blindness had experienced a lot of hardships, struggles, and challenges before they had fully developed self-acceptance. Thus, this research aims to explore on how the fifteen (15) respondents with adventitious blindness accepted themselves. A qualitative phenomenological type of research was used in gathering and interpreting the data of this research. Out of the gathered responses of the respondents, the researchers came up with a thematic analysis on the factors that led to self-acceptance called F-A-I-T-H. Each of the letters characterizes a significant representation of their personal outlook in their lives. Family support, achievement, inspiration, time, and hope are the pertinent variables leading to the road of self-acceptance.

Keywords: visual impairment; self-identity; faith; adventitious blindness; self-acceptance 


\section{Adventitious blindness: The road to self-acceptance}

\section{Introduction}

Acceptance of loss is a process of value changes (Dembo, Leviton, \& Wright, 1975; as cited in Carl, 2013). Hence, the absence of ability to unconditionally accept oneself can lead to a variety of emotional difficulties, including uncontrolled anger and depression (Carson \& Langer, 2006). People with adventitious disabilities, especially those with severe physical impairments, are likely to experience severe psychological trauma from both the personal loss and the changes from their former state. Consequently, people with adventitious disabilities may require greater effort and more time to adjust than those with congenital disabilities (Li \& Moore, 1998).

Of the five senses that human beings possess, sight has always been considered the most important. It has long been acknowledged that vision loss may bring about varying degrees of psychic suffering, undoubtedly greater than the distress resulting from other forms of sensorial impairment, at all ages (De Leo, Hickey, Meneghel, \& Cantor, 1999). Blindness is the impairment of visual function below a threshold. This threshold varies from context to context and standards for blindness vary across international and institutional borders (Ray, Cox, Jensen, Allen, Duncan, \& Diehl, 2016). In strict sense, blindness is the state of being totally sightless in both eyes and completely unable to see. Yet, it is commonly used as a relative term to signify visual impairment or low vision that even with eyeglasses, contact lenses, medicine, or surgery a person does not see well (Dahl, 2016). Likewise, it is a physical, psychiatric, intellectual, or sensory impairment whether temporary or permanent provided that it lasts for a significant period of time that limits the capacity to perform one or more essential activities of daily life. These can be caused or aggravated by economic and social environment (Ishtiaq, Chaudhary, Rana, \& Jamil, 2016; Fasina \& Ajaiyeoba, 2003).

In the world population estimated at 6,697 billion in 2010, there are more or less 39 million people who are blind (Mariotti \& Pascolini, 2011). On the contrary, in a survey conducted by Keeffe, Taylor, Fotis, Pesudovs, Flaxman, Jonas, and Bourne (2014) in Southeast Asia, blindness decreased significantly from $1.4 \%$ to $0.8 \%$ of the population, a hefty $43 \%$ reduction from 1990-2010. Relatively, it was found out that there were significantly more blind women (2.18 million) compared with men (1.28 million). All in all, there were 3.46 million blind people in Southeast Asia alone, in 2010. In the Philippines, on the third national survey on blindness it was identified that there were 29,888 people in 6,757 households in 2002. Of this number only $24,624(82.39 \%)$ were examined. The result of the survey revealed that the prevalence of bilateral blindness (both eyes are blind) is $0.58 \%$ while monocular blindness (only one eye is blind) and is $0.71 \%$ nationwide. Regionally, the prevalence of blindness is from $0.16 \%$ to $1.08 \%$ (Cubillan \& Olivar-Santos, 2005).

Blindness is categorized into two: congenital blindness and adventitious blindness (Moore, Graves, \& Patterson 1997; Hupp, 2003). However, Hartsock (2008) believes that there are three kinds of blindness: congenital blindness, blindness in old age, and adventitious blindness but, Getzel and Mellor (1985) said that blindness in old age is adventitious. Moreover, congenital blindness refers to a condition of blindness that is already present at birth or occurs at an early age. However, individuals who at one time were sighted but subsequently lost their vision are described as having an adventitious blindness (Kitchin \& Freundschuh, 2000; Sen, 1988; Holbrook \& Koenig, 2000; Moore, Graves, \& Patterson, 1997; Hupp, 2003). In addition, adventitious blindness refers to an individual who becomes blind after five years of age, meaning individuals with this type of blindness will probably have some visual memory and can use visualization (Sardegna, Shelly, Rutzen, \& Steidl, 2002). In general, adventitious blindness is the terminology used to refer to vision loss after years of sight (Turner, 2005).

In 2002, cataract, trachoma, and glaucoma were named as the three main causes of adventitious blindness, 
worldwide. Amongst, cataract is identified to be responsible for half of all blindness and is largely related to the ageing process (the older a person, the greater the chance of developing a cataract) all over the world. Second is trachoma which is responsible for 6 million blinded people or 15\% of world's blindness. Lastly, but still as serious as the other causes is glaucoma which is responsible for 5.2 million blind people or $13.50 \%$ of the total burden of world blindness and is therefore, considered to be the third largest cause of blindness worldwide (Roodhooft, 2002).

Over the years, cataract and glaucoma remained as the two most leading causes for blindness. On the contrary, in 2010, the identified third leading cause is age-related macular degeneration (Global Burden of Disease Study, 2010, as cited in Jonas, 2014). Age-related macular degeneration is defined as an ocular disease leading to loss of central vision in the elderly (Mardin, 2004). A scan of research literatures showed that studies on visual impairment and blindness greatly focused on self-determination (Robinson \& Lieberman, 2004; Agran, Hong, \& Blankenship, 2007; McDonall \& Crudden, 2009); self-concept (Lifshitz, Hen, \& Weisse, 2007; Halder \& Datta, 2012; Al-Zyoudi, 2007); and self-esteem (Salehi, Azarbayejani, Shafiei, Ziaei, \& Shayegh, 2015; Griffin-Shirley \& Nes, 2005; Bowen, 2010; Papadopoulos, Paralikas, Barouti, \& Chronopoulou, 2014). Most of these researches state that some young children with visual impairments have negative self-images and they view themselves as failures, have negative thoughts about themselves, dependent on their parents and others, and have feelings of loss if the disability was adventitious (Vernon, 1993, as cited by Griffin-Shirley \& Nes, 2005). Moreover, as their self-concept is viewed negatively their self-determination and locus of control in many youths are affected (McDonall \& Crudden, 2009)

On the effects of visual impairment to self-determination, they found out that the participants' levels of visual acuity significantly affected their opportunities for self-determination with regard to school and health care. However, significant differences were not found in the domains of at home, with friends, and physical education (Robinson \& Lieberman, 2004). Tantamount to this, the findings of a research conducted regarding the promotion of self-determination of students with visual impairments suggest that the respondents believed that self-determination is more important for students with low vision than for those who are blind (Agran, Hong, \& Blankenship, 2007).

In a research conducted by Lifshitz, Hen, and Weisse (2007), similar self-concept profiles were found for the adolescents with or without visual impairments in all categories, indicating a similar hierarchy of key figures for both groups. The participants exhibited lower scores on attitudes toward the disability and acceptance of the disability, whereas their scores on attribution style were significantly higher. Similarly, another research focused on adolescents who are sighted and visually impaired. The sighted ones scored higher in the total self-concept scores as compared to the adolescents who are visually impaired (Halder \& Datta, 2012). In connection, gender differences in self-concept among adolescents with low vision was researched on and the findings were young women had a lower self-perception than young men in three of the components evaluated (social self-concept, family self-behavior, and moral self-behavior). It is important to note; however, that their physical self-concept was higher (Al-Zyoudi, 2007).

People with visual disability have lower self-esteem and social skills than sighted people (Salehi, Azarbayejani, Shafiei, Ziaei, \& Shayegh, 2015). Regarding self-esteem and empathy in persons with visual impairment, the findings of a study showed that there were no significant differences between the sighted and visually impaired children for levels of self-esteem and empathy toward others (Griffin-Shirley \& Nes, 2005). In another study where the self-esteem of 60 children with visual impairment (VI) was measured using the BG STEEM Questionnaire, the results showed that overall, 70 percent of the children scored within the "normal" or "high" levels of self-esteem. The results also revealed that the degree of visual impairment may be a factor in determining self-esteem (Bowen, 2010).

On the other hand, adults with visual impairment who have higher external locus of control tended to have less self-esteem and higher levels of depression, melancholia, anxiety, and asthenia (Papadopoulos, Paralikas, 
Barouti, \& Chronopoulou, 2014). Individuals with an inner locus of control assume responsibility for their own behavior; they are more confident and active in their planning or decision-making and ready to believe that success follows on from their own efforts (Webster \& Roe, 1998, as cited in Papadopoulos et al., 2014).

Based on the above researches, it is clear that self-acceptance is missing. It is a general understanding that before a person develops his self-determination, self-concept, and self-esteem one must have to accept himself first. In particular, low self-esteem in any level reflects a dysfunctional habit of globally evaluating one's worth; therefore, it would be preferable to accept oneself unconditionally first (Chamberlain \& Haaga, 2001). The following literatures bring the idea that self-acceptance is necessary for every person to survive and face all the challenges with a happy disposition in life.

Self-acceptance is defined as holding a positive regard for or attitude toward oneself as a whole including one's past life experiences. It does not only rely on the approval of others but most importantly on one's personal achievements (Ellis, 2005, as cited in Rodriguez, Wei, Xiaoming, \& Xinghua, 2015; Morgado, Campana, \& Tavarez, 2014). Hence, having a stable state of personality may result from an individual's relatively stable self-estimation especially when comparing oneself with other people, means having accepted one's self (Stanik, 1998, as cited in Walecka-Matyja, 2014).

Three main attitudes are markedly inherent in self-acceptance. These are body acceptance, self-protection from negative judgments from others, and feeling and believing in one's capacities (Morgado, Campana, \& Tavares, 2014). Furthermore, self-acceptance meets a majority of the criteria by which a human quality or characteristic qualifies as a positive strength or virtue including: contributes to the individual's fulfillment; is morally valued; does not diminish other people in any way; occurs in a variety of situations and behaviors; is distinct from other positive traits, is embodied in "consensual paragons"; and the extent of negative behavior when the quality is absent (Peterson \& Seligman, 2004, as cited in Bernard, 2013).

\subsection{Statement of the Problem}

In a greater understanding, self-acceptance is crucial to mental health (Carson \& Langer, 2006). It is considered by most psychologists and mental health experts to be one of the important features among mental health and adjustment criteria (Ceyhan \& Ceyhan, 2011). Without self-acceptance, a person can make little or no progress in effective relationships (Matthews, 1993). Thus, with the above researches and literatures reviewed, this study on self-acceptance of people with adventitious blindness was conceptualized. Specifically, it sought to answer the question:

$>$ How self-acceptance was achieved by people with adventitious blindness?

\subsection{Significance of the Study}

This research will be of value to people who at present have a hard time accepting their condition of having adventitious blindness. Further, results of this study could benefit the family, teachers, relatives, and the immediate community of persons with adventitious blindness to become aware and better understands the condition of people with such condition. Likewise, this is an avenue for government and non-government organization to plan, organize, and implement a desired program that would help those people who are experiencing blindness, in general.

\section{Methodology}

\subsection{Research Design}

A qualitative research was used by the researchers because this research involves studying the meaning of people's lives under real-world conditions (Yin, 2011). Specifically, phenomenology was employed since it 
attempts to forage through the layers of lived experiences and cultural knowledge in order to rediscover experience before knowledge and beliefs are used to make a new sense out of experience (Oiler, 1986, as cited in Davis, n.d.). By means of a comprehensive face to face interview, informative data were gathered in order to thoroughly understand the respondents' life experiences that paved the way to self-acceptance.

\subsection{Participants and Setting}

Fifteen (15) people with adventitious blindness from Baguio City, Philippines were identified through a snowballing technique. Snowballing technique is a technique for finding research subjects. One subject gives the researchers the name of another subject, who in turn provides the name of a third, and so on (Vogt, 1999 as cited in University of Surrey, 2001). The participants must have self-proclaimed and fully pledged that they have already self-accepted their condition. Table 1 shows the demographic information of the participants. All the information is accurate except for their names to protect their identities.

Table 1

Demographics

\begin{tabular}{lllll}
\hline \multicolumn{1}{c}{ Participants } & Gender & \multicolumn{1}{c}{ Age } & \multicolumn{1}{c}{ Cause of Blindness } & \multicolumn{1}{c}{ Occupation } \\
\hline Jenny & Female & 22 years old & Cataract & Massage Therapist \\
Rommel & Male & 32 years old & Chicken Pox & Physical Therapist \\
Eric & Male & 53 years old & Accident & None \\
Ronny & Male & 22 years old & Cataract & Student \\
Kristine & Female & 34 years old & Optic Tumor & Massage Therapist \\
Donnie & Male & 38 years old & German Measles & Street Singer \\
Charles & Male & 19 years old & Glaucoma and Cataract & Student \\
Ivan & Male & 25 years old & Underdeveloped Cornea & Student \\
Miley & Female & 47 years old & German Measles & Street Singer \\
Jessica & Female & 36 years old & Unknown Cause & None \\
Lino & Male & 50 years old & Unknown Cause & Beggar \\
Brian & Male & 53 years old & German Measles & Massage Therapist \\
Neri & Female & 42 years old & German Measles & Massage Therapist \\
Ronald & Male & 58 years old & German Measles and Chicken Pox & None \\
Franchesca & Female & 23 years old & German Measles & Student \\
\hline
\end{tabular}

\subsection{Materials and Procedures}

An audio recording device served as a tool in capturing the participants' responses during the interview. The questions were stated orally and were recorded. Moreover, guide questions were utilized during the interview with some follow up questions that developed deeper understanding about the participants' answers. A notepad served as a tool in jotting down other necessary information of the participants' during the interview. It served as a tool for writing down key concepts and summarizing the participants' answers. A formal entrance from the researchers explaining the aim and significance of the participants" in the attainment of the research was conducted. Interviews were administered in a minimum of 45 minutes and were based on the participants' availability. Furthermore, anonymity and confidentiality of gathered answers were assured. The interpretation and analysis of data were coded and thematized. Warm and cool analyses were employed. The cool analysis part consisted of the identification of the significant statements or verbalizations of each respondent. These statements served as basis in the conduct of the warm analysis stage where data categories were formulated and themes evolved (De Guzman \& Tan, 2007). The researchers went back to the participants' for clarification and verification of their responses.

The following are the steps that were followed in analyzing the data gathered based from the study of Entwistle and Marton (1994):

Transcribing of all interviews in verbatim format;

Analysis of the transcripts of interviews; 
Catama, B. V., Del Castillo, A. L. A., Espino, A. G. S., \& et al.

$>$ Coding of statements in the transcripts considered significant to the research problem;

$>$ Consolidation of significant statements per transcript;

- Grouping of significant statements into categories across the transcripts based on similarities and differences;

$>$ Identification of emerging themes that became the recognized conceptions;

> Selection of specific responses (in "quotations") that best represent the discerned conceptions in each theme including translation in English if thoughts were expressed in Filipino language or in any other dialect; and

$>$ Provision of identification for each quoted idea to include gender and age, for example (Female, 22 years old).

\subsection{Ethical Consideration}

Ethical principles were applied in the whole process of the study. Before the actual interview to the targeted population, the researchers asked the approval of the Dean of the School of Teacher Education and Liberal Arts, Saint Louis University through a letter which was noted by the research coordinator and by the faculty research promoter. Approval and consent letters were given and read to the participants' before the data collection. Moreover, the decision of the participants' to partake in the study was highly respected. Before the interview proper, the participants' were asked for their permission in recording the interview and documenting the process. It was also thoroughly explained that all information that will be disclosed throughout the study would be kept confidential and anonymity of the participants' will be assured.

\section{Results and Discussions}

Based from the research conducted, the following are the main causes on how the respondents acquired adventitious blindness. Out of the fifteen (15) respondents, five (5) or $33.33 \%$ were caused by eye-related diseases such as cataract, underdeveloped cornea, and eye tumor; seven (7) or $46.67 \%$ were due to non-eye related diseases such as German measles and chicken pox; one (1) or $6.67 \%$ was caused by accident; and two (2) or $13.33 \%$ were results of unknown cause. From the cool and warm analyses of study, findings of this narrative interpretative inquiry have surfaced an interesting concept called F-A-I-T-H (Family Support, Achievement, Inspiration, Time, and Hope). Table 2 presents the categories on how self-acceptance was achieved by people with adventitious blindness.

Table 2

Self-Acceptance Categories

\begin{tabular}{|c|c|c|c|}
\hline Category & Male & Female & Total \\
\hline 1. Family Support & $12^{1}(30)^{2}$ & $14(35.9)$ & $26(32.9)$ \\
\hline Advices & $3(7.5)$ & $2(5.1)$ & $5(6.3)$ \\
\hline Guidance & $3(7.5)$ & $4(10.2)$ & 7 (17.9) \\
\hline Emotional Support & $2(5)$ & $5(12.8)$ & 7 (17.9) \\
\hline Physical Support & $4(10)$ & $3(7.7)$ & $7(17.9)$ \\
\hline 2. Achievements & $12(30)$ & $7(18)$ & $19(24.1)$ \\
\hline Own / Self & $3(7.5)$ & $2(5.1)$ & $5(6.3)$ \\
\hline Other People & $1(2.5)$ & $2(5.1)$ & $3(3.8)$ \\
\hline Academic & $3(7.5)$ & $1(2.6)$ & $4(5.1)$ \\
\hline Life & $5(12.5)$ & $2(5.1)$ & 7 (17.9) \\
\hline 3. Inspiration & $5(12.5)$ & $6(15.4)$ & $11(13.9)$ \\
\hline From others & $2(5)$ & $4(10.2)$ & $6(7.6)$ \\
\hline For others & $3(7.5)$ & $2(5.1)$ & $5(6.3)$ \\
\hline 4. Time & $6(15)$ & $4(10.2)$ & $10(12.7)$ \\
\hline Realizations & $2(5)$ & $1(2.6)$ & $3(3.8)$ \\
\hline Reflection & $4(10)$ & $3(7.7)$ & $7(17.9)$ \\
\hline 5. Hope & $5(12.5)$ & $8(20.5)$ & $13(16.5)$ \\
\hline In one's self & $2(5)$ & $3(7.7)$ & $5(6.3)$ \\
\hline In God & $3(7.5)$ & $5(12.8)$ & $8(10.1)$ \\
\hline
\end{tabular}

Note. ${ }^{1}$ Frequency response. ${ }^{2}$ Percentage within the group. 
Drawing from the result of the study, a simulacrum called "Adventitious Blindness Train of Self-acceptance" was created to represent the factors on how the respondents with adventitious blindness achieved self-acceptance out of their condition.

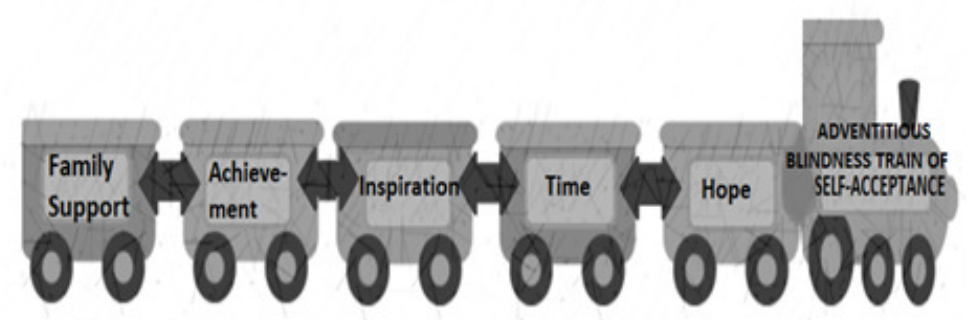

Figure 1. Adventitious blindness train of self-acceptance

\title{
3.1 Family Support
}

Family is the smallest unit of a society and, therefore, critical to its development and maintenance (Enrique, Howk, \& Huitt, 2007). It forms a crucial social safety net for improving the well-being of individual family members and promoting social cohesion more widely (Daly, O’Leary, \& Ireland, 2004). Additionally, family support is about recognizing and responding to the needs of families, especially in times of difficulty. The family must define their own need or problem and the necessary support must be made available when needed (Devaney, 2013). Family support plays an important role for it may be able to help reduce stressors and add to protective factor in a child's life (Canavan, Dolan, \& Pinkerton, 2000). Thus, an individual's correct development including the formation of personality, self-image, self-acceptance, and the relation to oneself as well as to other people results from family experience (Reykowski, 1992; as cited in Walecka-Matyja, 2014).

One of the factors that led to the self-acceptance of the respondents is the support of their families. One of the respondents claimed that before accepting himself, he underwent personal challenges like difficulties in adjusting, accepting his condition, and experiencing depression. Depression is the emotional expression of a state of ego-helplessness and ego-powerlessness to live up to certain strongly maintained narcissistic aspirations (Bibring \& Greenacre, 1953, as cited in Gieger, 1982). It causes significant suffering as well as impairments in physical, mental, and social functioning and is a common problem among older adults (Alexopoulos, 2005 as cited in Lee, Conwell, Shah, Barker, Delavan, \& Friedman, 2008). Since depression is only one of the many possible emotional responses to disability fundamental connection between loss and depression leads to a natural conceptual bridge that warrants attention (Langer, 1994).

In as much that family support is service-oriented to the relational well-being and functioning of children and families (Pinkerton, Dolan, \& Canavan, 2004 as cited in Daly, Bray, Bruckauf, Byrne, Margaria, Pec'nik, \& Samms-Vaughan, 2015), the sacrifices of his parents for him to have his surgeries abroad served as the only factor that changed him and his outlook in life that later led to self-acceptance. His parents served as his strength to stand up despite being nearly suicidal and continue life. He also wanted to return all the sacrifices of his parents and pay them back.

\begin{abstract}
"My parents are the most influential people who have changed my outlook in life. They had shown me the true meaning of sacrifice, love and on how to live with positivity in life. They did everything to process my papers for my eye surgery abroad hoping that I can recover from adventitious blindness. Indeed, my parents are my strength. Without them, I am useless." - [Male, 25 years old]
\end{abstract}

A lady respondent exclaimed that before she attained self-acceptance, she had experienced difficulties not only with her personal dealings but with her own family. She expounded that her family felt depressed because they thought that their expectations wouldn't be met by their daughter. In this regard, her family had changed their way of dealing with her. Her family, most especially her parents were feeling anxious and despair. They do not want to talk about her condition which explains that support is evidently absent. She felt vulnerable, lost hope to 
continue life, and started questioning her own existence that resulted to the decadence of pursuing her dreams and ambitions in life. Moreover, she experienced low self-esteem which triggered intense bitterness and anger. Nevertheless, her parents were on the stage of denial which acted as a buffer that gives the person time to regroup, take stock, and eventually mobilize other defenses (Joshi, Lewin, \& O'Donnell, 2005). Ziolko (1991) suggests that when parents are told of a child's disability, they go through a multi-stage adaption period which includes: withdrawal or rejection, denial, fear and frustration, and adjustment. Therefore, when a family has a child with disability the parents may have a range of emotional responses that all family members experience at various times (Sands, Kozleski, \& French, 2000 as cited in Gallagher, Fialka, Rhodes, \& Arceneaux, 2002). After her family's adjustment period, they were the ones who supported her and helped her and they never neglected her and made sure that they are always there for her. If the family succeeds in rising to the challenge and enduring these crises it is tantamount to acceptance (Kandel \& Merrick, 2007). Somehow, it is still her family that made her accept herself.

"The moment that my family had adjusted with regards to my situation, they never stopped to give me support and never neglected me. They were always there when I needed them. And because of their undeniable effort, I was able to accept myself." - [Female, 34 years old]

Based on the Double ABCX Framework or the Theory of Family Stress and Adaptation, coping with a crisis is related to adaptation. Parents' coping strategies are important management resource during a family crisis since it allows the family to eliminate, reduce, or avoid stressors and strains, manage the situation, and implement changes where necessary in order to maintain the family system (Smith, \& In Liehr, 2014). Therefore, family's adaptability, a family's flexibility and ability to adjust its relationships and habits to change is an important variable in healthy families and in good adjustment in young people and it is known to be related to strong attachments (Pfaller, Kiselica, \& Gerstein, 1998 as cited in Heatherington \& Lavner, 2008).

Another lady respondent also revealed that she experienced being bullied by both children and older people. Bullying is the set of physical and/or verbal behaviors that a person directs or group of persons direct against a peer, in hostile, repetitive and ongoing fashion, abusing real or fictitious power with the intent to cause harm to the victim (Olweus, 1993 as cited in Benitez \& Justicia, 2006). General Strain Theory argues that individuals who experience a strain (e.g. bullying) may produce negative emotions such as anger, frustration, depression, or anxiety which may lead to a corrective action in terms of wrongdoing, self-harm, suicide, etc. (Agnew, 1992 as cited in Eriksen, Nielsen, \& Simonsen, 2012). However, according to Seltzer (2008), accepting one's self unconditionally despite deficiencies would have been almost automatic if the parents conveyed a predominantly positive message about it; and, additionally, if one grew up in a generally supportive environment. Similarly, in her case, her family members were the ones who helped her accept her condition by telling her and making her feel who she is even at a young age. Despite her condition, they still accepted her and even exerted effort in making the society accepts her as she is.

\footnotetext{
"Despite my condition, my family still accepted me. They let me realize who I really am. They exerted an effort to make the people around me understand my situation. As a result, I was able to accept myself because of them." - [Female, 36 years old]
}

Therefore, it can be said that there is no doubt that the family plays an important role in the emotional and cognitive development of every individual (Sungh \& Udainiya, 2009; Church, 1987 as cited in Garcia \& Sison, 2012). It is suggested that bonds between parents and children appear to be important to a child's well-being as parents are able to lower their child's anxiety by their warmth and attention (Browne \& Shlosberg, 2006 as cited in Garcia \& Sison, 2012) which means that the family has an influence on happiness during the whole life whether the person is young or old (Wu, 2014).

\subsection{Achievements}

Another crucial factor culled from the respondents' responses that led them to self- acceptance is their achievements. Achievement is seen as something that has been accomplished, especially by hard work, ability, or 
heroism (Ndukaihe \& Fonk, 2008). According to McClelland's Theory of Need, the need for achievement describes a person's drive to excel with respect to some established set of standards. Moreover, individuals' achievement needs are satisfied when they are able to actualize their own purposes relative to and regardless of the situations of others (Yamaguchi, 2003 as cited in Todd Royle \& Hall, 2012). Although achievement needs may be measured in terms of mastery and competitiveness, they may also be reflected in the desire to excel in relation to themselves (Heintz \& Steele-Johnson, 2004 as cited in Todd Royle, 2006).

On another instance, a lady respondent averred that during her journey to self-acceptance, she had experienced different personal struggles such as self-pity and low self-confidence. She also had difficulties in travelling and going to other places alone. Notwithstanding her struggles, she managed to achieve self-acceptance after undergoing training. Because of that, she tended to search for people with same condition to experience a proactive socialization. Accordingly, the need for socialization is an outlet of a healthy living in advancing one's perspectives in life. Socialization is termed as the lifelong process of social interaction through which individuals acquire self-identity and the physical, mental, and social skills needed for survival in society (Kendall, 2007). Her training also became an avenue for her to boost her self-confidence because she knew that she was doing something desirable for her future. Consequently, it is believed that having confidence suggests a high level of self-assurance since it involves the belief that things will turn out well (Craig, 2007).

"During the training I was able to interact and socialize with people with the same condition as mine. There was a boost in my confidence knowing that I am doing something desirable for my future. After attending the training, I began to accept myself." - [Female, 22 years old]

This was supported by another respondent who exclaimed that his achievements are the reason for his self-acceptance. Prior to that, he also had struggled on how people bullied him with degrading words that resulted to low self-esteem and self-confidence. Self-esteem is a person's judgment of his/her self-concept and self-worth. Individuals with low self-esteem is likely to be self-protective. They are motivated to avoid situations that could cause failure, embarrassment, or humiliation (Baumeister, 1989, as cited in Petty, 2008). Self-confidence is often essential for success. Lack of self-confidence seems to gnaw away at some people's ability to get things done well because they seem to realize their own self-doubts in their work (Grigorenka \& Sternberg, 2007). Somehow, his inclination to music and sports served as an avenue to prove that he has something to excel on. It turned out to be his way of expressing himself to better manage his life.

\section{"Being known in music and sports, I proved myself that I am good at some things. Through this, I was able to boost my confidence. Also, I attained self-acceptance along the way." - [Male, 22 years old]}

Waterman (2008) as cited in Szentagotai \& David (2013) posits that happiness is equated with the positive affect resulting from getting the material goods one wishes to possess or from the action opportunities one wishes to experience. The Theory on Self-efficacy believes that self-efficacy can influence an individual to become committed to successfully execute the behaviors necessary to produce desired outcomes (Landry, 2003). To support this, the Proactive Personality and Career Success Theory states that people who are highly proactive identify opportunities and act on them, show initiative, and persevere until they bring about meaningful change. They transform their missions, find and solve problems, and take it on themselves to have an impact in the world around them (Bateman \& Crant, 1993, as cited in Crant, Kraimer, \& Seibert, 1999).

\subsection{Inspiration}

Inspiration is said to lead individuals to make productive life choices (Reese, Kim, Palak, Smith, \& Howard, 2005). It is also known to boost a person or even groups or societies from the challenging and impossible status to the enjoyable and possible achievements (Buheji, Saif, \& Jahrami, 2014). Hence, elusive goods cannot easily be gotten through a straightforward process of approach and acquisition. Instead, they are realized or brought into fruition and inspiration which plays a critical role in this process (Thrash, Moldovan, Oleynick, \& Maruskin, 
2014).

Different challenges were faced by one of the respondents before self-acceptance came into realization. Aside from being bullied, discrimination was one of the major obstacles in his adjustment period. According to European Commission (2015), discrimination can be direct or indirect. Direct discrimination is where a person is treated differently and worse than others, while indirect discrimination is where a practice, policy, or rule that applies to everyone has a worse effect on some people compared to others. Adults with disability are twice as likely as adults without a disability to say that their life has been harder because of discrimination and that it has interfered with them being able to live a full and productive life (American Psychological Association, 2016).

As such, he elaborated that he was being discriminated not only because he is blind but also because he is homosexual. The place where he was born is conventional. Most of the people around him made him the center of ridicule where he experienced self-pity. Self-pity is a prevalent response to stressful events. It is often accompanied by feelings of sadness and a heightened sense of injustice (Stoeber, 2003). Despite of that, self-pity and discrimination served as his major inspiration to stand tall and prove that he can live independently with conviction. Henceforth, it served as his strength and inspiration to value life.

"Self-pity and discrimination from other people served as my inspiration to accept myself. I told myself that these people would serve as my strength. I want to prove them that I can live independently with conviction. They inspired me and let me appreciate life even more." - [Male, 19 years old]

Another respondent declared that the importance of thinking about what the future can bring made her realize that there is no way of stopping her to pursue her goals and aspirations in life. She often thought of how to live independently in case her parents are not around or if they are already gone to support her basic needs and wants. Fortunately, she met a social worker from the Department of Social Welfare and Development (DSWD) who informed her about learning massage therapy. She was encouraged by the social worker's words of wisdom and pieces of advice that her disability is not a hindrance for success. Instead, it would just take hard work and determination to succeed in life where inspiration should be the very foundation to move forward. Indeed, the social worker had become her inspiration to continue life despite her condition.

"When I went here at Baguio City, a social worker saw me. She invited me to go to the DSWD office and join the massage therapy training. Through sheer determination, I went there and took the opportunity. Without the social worker, I am not here doing massage therapy. She inspired me not only through her deeds but also through her words of encouragement like "Being blind is not a hindrance to success." And the outcome for all of these is me accepting myself." - [Female, 47 years old]

Inspiration orients one toward something that is better or more important than one's usual concerns. It enables one to see better possibilities which are manifested in realization based on one's motivation and drive to think and work with optimism (Thrash \& Elliot, 2004). The essence of being motivated is anchored on the principle of Atkinson's Achievement Motivation Theory which states that achievement behavior is a behavior in which the goal is to develop or demonstrate - to self or to others-high ability, or not demonstrating low ability. This implies that in achievement situations individuals desire success to the extent that it indicates high ability and seek to avoid failure to the extent that it indicates low ability (McFarland \& Ross, 1982, as cited in Nicholls, 1984).

\subsection{Time}

Time is the organizing principle in one's daily life and its passage sweeps all from cradle to grave. It's not really possible to ignore time or its effects on people (Koscielniak, 2004). Knowing so, any process has its own time which characterizes the rate of this process. The rate of a process can change, so individual time is 
changeable (Bakman \& Pogorelsky, n.d.). Everything changes. Objects come into existence, last for a while, go out of existence, change their qualities and change in their relation to things. Nothing can persist through time and that all existence is momentary at best (Loux \& Zimmerman, 2003). Moreover, time is another factor that led to self-acceptance of some of the respondents. One of them said that before having self-acceptance, it takes certain struggles to undergo, may it be internal or external. He had struggles in travelling from one place to another, socializing with and trusting other people. Out of all the challenges that he underwent, time is greatly needed to surpass and learn the lessons of life. He is very positive of saying that all creations have their unique differences. There is no need for him to question or blame his parents regarding his condition, rather, for him, everyone will be able to accept themselves. It is just a matter of when is the right time.

"Well, that's life. Nothing would change even if I blame my parents for this impairment. God's creations are unique. Time is what I needed. Through time, I accepted my condition. Everyone would be able to accept one's self; it all just depends on when is the right time for them." - [Male, 32 years old]

Meanwhile, self-acceptance is very difficult to attain as mentioned by another respondent most especially if it is deeply rooted from the past. As shared, he was deprived of education due to poverty. Instead of attending school, he served as a caregiver to his niece and nephews including his younger siblings. With his personal deprivation in the past, he was able to overcome the trials that came along his way. Thus, the past served as a springboard for him to be directed in his own future. Through time, he was able to set aside his past and focus on what is present to contribute to his possible future. He learned that moving forward takes a lot of sacrifices, strong will, and a determined heart to partake a brighter future.

"Not being able to study because of poverty paved the way for me to overcome trials in my life. Because of time, I was able to forget and set aside my past. I learned to focus on what is present and to desire to move on even when it entails sacrifices, strong will, and a determined heart." [Male, 50 years old]

With the circumstances stated above, it can be assumed that it takes time and experience for one to develop the inner surety to accept because time allows one to accept and carry on - not to forget and not for the scars to disappear completely, just for the wounds to be healed (Ayello, Dowsett, Schultz, Sibbald, Falanga, Harding, Romanelli, Stacey, Teot, \& Vanscheidt, 2004). Everything takes time, and nothing goes on nonstop forever (Langley \& Tsoukas, 2017). One thing good about time is that it has the ability to fix things, to heal wounds (Boich, 2009), because time is a great healer ---grief, shock, wounded feelings, and so on will fade with time (Manser, Fergusson, \& Pickering, 2007). As the wounds heal one becomes receptive as he/she engages and makes conscious efforts to be sociable (Weil, 2004).

\subsection{Hope}

In setting goals, hope is a crucial component, in addition, to visualization of obstacles, and increasing will power in the effort of achieving a desired goal (Lueck, 2007). Though variously characterized as a cognitive attitude, an emotion, a disposition, and even a process or activity, hope, more deeply is a unifying and grounding force of human agency. We cannot live a human life without hope (McGeer, 2004) for hope plays an important role in one's illness experience (Nekolaichuk, 1999).

One of the respondents had given hope as her source of self-acceptance. Although she had experienced difficulties in going to school, doubts on her future, and struggles on how to face life without vision she still had high hopes because God is the primary source of joy and hope for man (John, Messori, Hammond, \& Bogert, 2004). According to her, Jesus was the reason for her to accept herself. One must pray to Jesus for He said that while there is life, there is hope. One must trust on Him for He will give. I just need to trust in Him for He is the best provider, he said. 
"Jesus was the reason for me to accept myself. Jesus said that while there is life, there is hope. Just trust in Him and He will give. I just needed to pray and trust in Him for I know that He is the best provider." - [Female, 30 years old]

On the other hand, one respondent exclaimed that before self-acceptance, one would still undergo difficult times in life and would still have resentments. MacLachlan (2010) explains that resentment is known as the anger that arises in response to a certain kind of threat: that is, an unjustified, intentional injury, harm, or insult to oneself, or those with whom one identifies closely. To her, she had a difficult time in accepting her condition because she was afraid of what might happen in the future. She had doubts that maybe her life would have no direction and she would have no chance of having her own family, though, it never hindered her in offering her life to God that even led her to accepting herself. She stated that there was a person who went to their house who was sharing the word of God. At that time she started to know her purpose in life and who she really is because of their teachings. And there, she was able to accept herself that also became the reason of her stronger faith.

"There was this one time when a person who was studying the word of God went to our house.

He let me realize the real purpose of my life and who I really was. Not only was I able to accept myself but also my faith in Him was made stronger. There were many resentments before acceptance came into my life." - [Female, 42 years old]

In this aspect, the respondent showed hope in God and accepted herself because spirituality and faith in God have a crucial role in shaping one's hope (Herth, 1990; Weaver, Flannelly, 2004 as cited in Wnuk, 2017). One cannot hope to live up to the highest ideals, but one can be true to his/her purpose of finding God (Aivazian, 2012). The consequences of obeying God gives hope (Gauvin, 2014). However, to hope is not only to relate oneself to God, but, also to relate to others (Pawar, 2009). It also reflects individuals' perceptions regarding their capacities to clearly conceptualize goals, develop the specific strategies to reach those goals, and initiate and sustain the motivation for using those strategies (Snyder, Lopez, Shorey, Rand, \& Feldman, 2003).

As regard another respondent, he said that before acceptance, there are still barriers that drag a person not to keep going. For him, he had a difficult time in travelling, adjusting, and accepting his condition especially during the first few years of having no vision that led him to having a low self-confidence. Despite of that, he believes that there will come a time when one would be starting to think of hoping and that's within a person's desire to move forward. Just like him, he began hoping and taking control of his life because he started accepting that the universe is a real bastard and it doesn't treat anyone fairly. He added that his hopes of having a bright future keep him going until he reaches the point of acceptance. Hope is more explicitly concerned with the self-initiated actions one can take to create a successful future for oneself (Arnau, Rosen, Finch, Rhudy, \& Fortunato, 2007; Gallagher \& Lopez, 2009 as cited in Alarcon, Bowling \& Khazon, 2013).

"There came a point in my life where I started to think "Okay", this is pathetic. I need to start hoping and taking control of my life.' And to start doing that I first should accept that the universe is a real bastard and it doesn't treat anyone fairly. It made me realize that I needed to have high hopes that there would still be a bright future for me. These high hopes were made out of my desire to continue life. It kept me going until the point of acceptance. And now, I am here studying for my dreams." - [Male, 25 years old]

Espinoza, Molinari, Etchemendy, Herrero, Botella, and Baños Rivera, (2016) deemed that hope is an important variable in the pursuit and achievement of our goals. It means having the will and determination to accomplish our goals and it also implies having the ability to use multiple strategies to reach them. Hope theory explains that higher hope is consistently related to better outcomes in physical health and psychological adjustment (Snyder, 2002). The hopelessness theory, in contrast, posits that people are vulnerable to depression because they tend to generate interpretations of stressful life events that have negative implications for their future and for their self-worth. People who generate these negative interpretations develop hopelessness (Haeffel, Abramson, Brazy, \& Shah, 2007). 
In a nutshell, F-A-I-T-H (family support, achievements, inspiration, time, and hope) is the primary reason on how the respondents with adventitious blindness achieved self-acceptance. "Faith" is nearly impossible to define. It varies depending on the perception of an individual for faith is understood to be intensely personal and often seen as extremely private (Newman, 2004). Nevertheless, the technical meaning of faith is firm belief in something real, based on evidence (al-Jifri, 2012). Moreso, faith is never just believing, faith is believing enough to act (Small Groups, n.d.), and is a kind of attitude of trust or assent (Farinaccio, 2002). Faith (in the family, achievements, in the things that inspire them, in the healing power of time, and in the presence of hope) was evidently seen in all the factors that made them accept themselves. Faith summarizes the five factors that emerged. The respondents believed that they started to act and do something that led them to self-acceptance.

\section{Conclusion and Recommendation}

Before fully developing self-acceptance, one may experience several struggles and challenges along the way. However, the exploration on how people with adventitious blindness accepted themselves plays a vital role since self-acceptance is known to be the very foundation of other areas of self-identity. As indicated by the findings of the study presented, there were five pertinent factors that emerged from the respondents' journey of self-acceptance. These factors are known to be: Family Support, Achievements, Inspiration, Time, and Hope.

Based on the interview conducted with the respondents, it was observed that these factors served as their primary source of self-acceptance. The support of the family members through the recognition of their needs and identities paved way to self-acceptance. In addition, the respondents' own achievements also served as one of the important variables for it became their avenue in boosting their self-confidence and self-esteem. Beyond the support of the family and their capabilities in achieving a goal, having an inspiration either those who helped them or those who discriminated them also resulted to their self-acceptance. Lastly, waiting for the right time and hoping not only to God's plans and graces but as well as one's own capacity to deal with things also led them to accepting themselves.

Despite the challenges faced by the respondents along their journey to self-acceptance, their outlooks in life remained positive. For them, though one may undergo different obstacles in life, there is still a high possibility that through different experiences and significant factors, one may be able to attain self-acceptance and have a happy disposition in life. Based on the findings, it is then recommended that future researchers shall explore on the impacts of self-acceptance on one's personal life and well-being. Moreover, it is suggested that future researchers shall delve into the struggles and challenges faced by people with congenital blindness and a correlational study on both congenital and adventitious blindness can also be a good subject.

\section{References}

Agran, M., Hong, S., \& Blankenship, K. (2007). Promoting the self-determination of students with visual impairments: Reducing the gap between knowledge and practice. Journal of Visual Impairment \& Blindness, 101(8), 453-464.

Aivazian, T. (2012). The British study edition of Urantia papers. Retrieved from http://urantiabook.org/downloads.htm

Alarcon, G. M., Bowling, N. A., \& Khazon, S. (2013). Great expectations: A meta-analytic examination of optimism and hope. Personality and Individual Differences, 54(7), 821-827. https://doi.org/10.1016/j.paid.2012.12.004

Al-Jifri, H. A. (2012). The concept of faith in Islam. Amman, Jordan: The Royal Aal Al-Bayt Institute for Islamic Thought.

Al-Zyoudi, M. (2007). Gender differences in self-concept among adolescents with low vision. International Journal of Special Education, 22(1), 132-136.

American Psychological Association. (2016). Stress in America: The impact of discrimination. Washington, DC: Stress in America Survey. 
Catama, B. V., Del Castillo, A. L. A., Espino, A. G. S., \& et al.

Ayello, E. A., Dowsett, C., Schultz, G. S., Sibbald, R. G., Falanga, V., Harding, K., Romanelli, M., Stacey, M., Teot, L., \& Vanscheidt, W. (2004). Time heals all wounds. Nursing Management, 34(4), 36-41. https://doi.org/10.1097/00152193-200404000-00040

Bakman, Y., \& Pogorelsky, B. (n.d.). The notion of time in special relativity. Tel-Aviv, Israel. Tel-Aviv University.

Benitez, J. L., \& Justicia, F. (2006). Bullying: Description and analysis of the phenomenon. Electronic Journal of Research in Educational Psychology, 4(2), 151-170.

Bernard, M. E. (2013). Strength of self-acceptance: Theory, practice, and research. New York, NY: Springer. https://doi.org/10.1007/978-1-4614-6806-6

Boich, R. (2009). Excuse me, your life is waiting! A bridge from addiction to early recovery. New York, NY: iUniverse.

Bowen, J. (2010). Visual impairment and its impact on self-esteem. British Journal of Visual Impairment, 28(1), 47-56. https://doi.org/10.1177/0264619609349429

Buheji, M., Saif, Z., \& Jahrami, Z. (2014). Why inspiration matters? Journal of Inspiration Economy, 1(1), $15-24$.

Canavan, J., Dolan, P., \& Pinkerton, J. (2000). Family support: Direction from diversity. London: Jessica Kingsley Publishers.

Carl, B. (2013). Acceptance of disability in college students (Doctoral dissertation). Retrieved from http://scholarsarchive.byu.edu/cgi/viewcontent.cgi?article $=5179 \&$ context=etd

Carson, S. H., \& Langer, E. J. (2006). Mindfulness and self-acceptance. Journal of Rational-Emotive \& Cognitive-Behavior Therapy, 24(1), 29-43. https://doi.org/10.1007/s10942-006-0022-5

Ceyhan, A., \& Ceyhan, E. (2011). Investigation of university students' self-acceptance and learned resourcefulness: A longitudinal study. Higher Education, 61(6), 649-661. https://doi.org/10.1007/s10734-010-9354-2

Chamberlain, J., \& Haaga, D. (2001). Unconditional self-acceptance and psychological health. Journal of Rationale-Emotive \& Cognitive-Behavior Theory, 19(3), 177-189. https://doi.org/10.1023/A:1011141500670

Craig, C. (2007). Creating confidence: A handbook for professionals working with young adults. Scotland, UK: The Centre for Confidence and Well-being.

Crant, S., Kraimer, M., \& Seibert, M. (1999). Proactive personality and career success. Journal of Applied Psychology, 84(3), 416-427. https://doi.org/10.1037/0021-9010.84.3.416

Cubillan, L., \& Olivar-Santos, E. (2005). Third national survey on blindness. Philippine Journal of Ophthalmology, 30(3), 100-108.

Dahl, A. A. (2016). Blindness: Get facts on types \& causes of vision loss. MedicineNet. Retrieved from http://www.medicinenet.com/blindness/article.htm

Daly, M. R., Bray, Z., Bruckauf, J., Byrne, A., Margaria, N., Pec'nik, \& M. Samms-Vaughan (2015). Family and parenting support: Policy and provision in a global context. Innocenti Insight. Florence. UNICEF Office of Research.

Daly, M., O'Leary, O., \& Ireland. (2004). Families and family life in Ireland: Challenges for the future. Report of public consultation fora. Dublin: Department of Social \& Family Affairs.

Davis, K. (n. d.). The phenomenology of research: The construction of meaning in composition research. Jac Online Journal, 15(1).

de Guzman, A. B., \& Tan, E. B. (2007). Understanding the essence of scholarship from the lived experiences of a select group of outstanding Filipino researchers. Educational Research Journal, 22(1), 49-68.

De Leo, D., Hickey, P. A., Meneghel, G., \& Cantor, C. H. (1999). Blindness, fear of sight loss, and suicide. Psychosomatics, 40(4), 339-344. https://doi.org/10.1016/S0033-3182(99)71229-6

Devaney, C. (2013). An evaluation of the implementation of the induction of social workers: A policy and guidelines for children and families social services. Dublin: Child and Family Agency.

Enrique, J., Howk, H., \& Huitt, W. (2007). An overview of family development. Educational Psychology Interactive. Valdosta, GA: Valdosta State University.

Entwistle, N., \& Marton, F. (1994). Knowledge objects: Understandings constituted through intensive academic 
study. British Journal of Educational Psychology, 64(1), 161-187. https://doi.org/10.1111/j.2044-8279.1994.tb01092.x

Eriksen, T. L., Nielsen, H. S., \& Simonsen, M. (2012). The effects of bullying in elementary school. Bonn, Germany: The Institute for the Study of Labor.

Espinoza, M., Molinari, G., Etchemendy, E., Herrero, R., Botella, C., \& Baños Rivera, R. M. (2016). Understanding dispositional hope in general and clinical populations. Applied Research in Quality of Life, 12(2), 439-450. https://doi.org/10.1007/s11482-016-9469-4

European Commission. (2015). Know your rights: Protection from discrimination. Luxembourg, EU: Publications Office.

Farinaccio, J. (2002). Faith with reason: Why Christianity is true? Pennsville, NJ: BookSpecs Publishing.

Fasina, F. O., \& Ajaiyeoba, A. I. (2003). The prevalence and causes of blindness and low vision in Ogun State, Nigeria. African Journal of Biomedical Research, 6, 63-67.

Gallagher, P., Fialka, J., Rhodes, C., \& Arceneaux, C. (2002). Working with families: Re-thinking denial. Young Exceptional Children, 5(2), 11-17. https://doi.org/10.1177/109625060200500202

Garcia, J. A., \& Sison, K. G. (2012). Locus of hope and subjective well-being. International Journal of Research Studies in Psychology, 1(3), 53-58. https://doi.org/10.5861/ijrsp.2012.297

Gauvin, J. (2014). The other side of the Holy cover: Hundreds of Bible-based articles. Canada: ISBN Canada.

Getzel, G. S., \& Mellor, M. J. (1985). Gerontological social work practice in the community. New York: Haworth Press.

Gieger, R. (1982). Depression in adolescence: Theories of casualties and treatment modalities (Unpublished master's thesis). California State University, Northridge.

Griffin-Shirley, N., \& Nes, S. L. (2005). Self-esteem and empathy in sighted and visually impaired pre-adolescents. Journal of Visual Impairment \& Blindness, 99(5), 276-285.

Grigorenko, E., \& Sternberg, R. (2007). Teaching for successful intelligence: To increase student learning and achievement (2nd ed.). Thousand Oaks, CA: Corwin Press.

Haeffel, G. J., Abramson, L. Y., Brazy, P. C., \& Shah, J. Y. (2007). Hopelessness theory and the approach system: Cognitive vulnerability predicts decreases in goal-directed behavior. Cognitive Therapy and Research, 32(2), 281-290. https://doi.org/10.1007/s10608-007-9160-z

Halder, S., \& Datta, P. (2012). Insights into self-concept of the adolescents who are visually impaired in India. International Journal of Special Education, 27(2), 86-93.

Hartsock, C. (2008). Sight and blindness in Luke-Acts: The use of physical features in characterization. Leiden: Brill.

Heatherington, L., \& Lavner, J. A. (2008). Coming to terms with coming out: Review and recommendations for family systems-focused research. Journal of Family Psychology, 22(3), 329-343. https://doi.org/10.1037/0893-3200.22.3.329

Holbrook, M., \& Koenig, A. (2000). Ensuring high-quality instruction for students in Braille literacy programs. Journal of Visual Impairment \& Blindness, 94(11), 677-694.

Hupp, G. S. (2003). Cognitive differences between congenitally and adventitiously blind individuals. (Unpublished dissertation.) University of North Texas, United States of America.

Ishtiaq, R. (2016). Psychosocial implications of blindness and low vision in students of blind school Bahawalpur. Pakistan Journal of Medical Sciences, 32(2), 431-434. https://doi.org/10.12669/pjms.322.8737

John, P., Messori, V., Hammond, E., \& Bogert, W. (2004). Crossing the threshold of hope. Santa Ana, CA: Books on Tape.

Jonas, J. B. (2014). Global prevalence of age-related macular degeneration. The Lancet Global Health, 2(2), e65-e66. https://doi.org/10.1016/S2214-109X(13)70163-3

Joshi, P., Lewin, S., \& O'Donnell, D. (2005). The handbook of frequently asked questions following traumatic events: Violence, disasters, or terrorism. Washington, DC: The International Center to Heal Our Children: Building Healthy Minds and Futures, Children's National Medical Center.

Kandel, I., \& Merrick, J. (2007). The child with a disability: Parental acceptance, management and coping. The Scientific World Journal, 7, 1799-1809. https://doi.org/10.1100/tsw.2007.265 
Catama, B. V., Del Castillo, A. L. A., Espino, A. G. S., \& et al.

Keeffe, J., Taylor, H. R., Fotis,, K., Pesudovs, K., Flaxman, S. R., Jonas, J. B., Bourne, R. R. (2014). Prevalence and causes of vision loss in Southeast Asia and Oceania: 1990-2010. British Journal of Ophthalmology, 98(5), 586-591. https://doi.org/10.1136/bjophthalmol-2013-304050

Kendall, D. (2007). Sociology in our times: The essentials (4th ed.). Boston, MA: Cengage Learning.

Kitchin, R., \& Freundschuh, S. (2000). Cognitive mapping: Past, present, and future. London: Routledge.

Koscielniak, B. (2004). About time: A first look at time and clocks. Boston: Houghton Mifflin Company.

Landry, C. C. (2003). Self-efficacy, motivation, and outcome expectation correlates of college students' intention certainty. (Unpublished doctoral dissertation). Louisiana State University and Agricultural and Mechanical College.

Langer, K. G. (1994). Depression and denial in psychotherapy of persons with disabilities. American Journal of Psychotherapy, 48(2), 181-194.

Langley, A., \& Tsoukas, H. (2017). The Sage handbook of process organization studies. Thousand Oaks, CA: SAGE Publishing Inc.

Lee, B. W., Conwell, Y., Shah, M. N., Barker, W. H., Delavan, R. L., \& Friedman, B. (2008). Major depression and emergency medical services utilization in community-dwelling elderly persons with disabilities. International Journal of Geriatric Psychiatry, 23(12), 1276-1282. https://doi.org/10.1002/gps.2063

Li, L., \& Moore, D. (1998). Acceptance of disability and its correlates. The Journal of Social Psychology, 138(1), 13-25. https://doi.org/10.1080/00224549809600349

Lifshitz, H., Hen, I., \& Weisse, I. (2007). Self-concept, adjustment to blindness, and quality of friendship among adolescents with visual impairments. Journal of Visual Impairment \& Blindness, 101(2), 96-107.

Loux, M., \& Zimmerman, D. (2003). The Oxford handbook of metaphysics. New York, NY: The Oxford University Press, Inc.

Lueck, M. A. (2007). Hope for a cause as cause for hope: The need for hope in environmental sociology. The American Sociologist, 38(3), 250-261. https://doi.org/10.1007/s12108-007-9017-7

MacLachlan, A. (2010). Unreasonable resentments. Journal of Social Philosophy, 41(4), 422-441. https://doi.org/10.1111/j.1467-9833.2010.01508.x

Manser, M., Fergusson, R., \& Pickering, D. (2007). The facts in file dictionary of proverbs. New York, NY: Facts on File.

Mardin, C. (2004). Age-related macular degeneration. Orphanet Encyclopedia. Retrieved from https://www.orpha.net/data/patho/GB/uk-ARMD.pdf

Mariotti, S. P., \& Pascolini, D., (2011). Global estimates of visual impairment: 2010. British Journal of Ophthalmology, 96(5), 614-618.

Matthews, D.W. (1993). Acceptance of self and others. North Carolina: North Carolina Cooperative Extension Service.

McDonnall, M., \& Crudden, A. (2009). Factors affecting the successful employment of transition-age youths with visual impairments. Journal of Visual Impairment \& Blindness, 103(6), 329-341.

McGeer, V. (2004). The art of good hope. Annals of the American Academy of Political and Social Science, 592(1), 100-127. https://doi.org/10.1177/0002716203261781

Moore, J. E., Graves, W. H., \& Patterson, J. B. (1997). Foundations of rehabilitation counseling with persons who are blind or visually impaired. New York, USA: AFB Press.

Morgado, F. R., Campana, A. B., \& Tavares, M. F. (2014). Development and validation of the self-acceptance scale for persons with early blindness: The SAS-EB. Plos ONE, 9(9), 1-9. https://doi.org/10.1371/journal.pone.0106848

Ndukaihe, V. E., \& Fonk, P. (2008). Achievement as value in the Igbo/African identity: The ethics. Berlin: Lit.

Nekolaichuk, C. (1999). The meaning of hope in health and illness. Bioethics Forum, 15(1), 14-20.

Newman, L. (2004). Faith, spirituality, and religion: A model for understanding the differences. Faith, Spirituality, and Religion on Campus, 23(2). Retrieved from http://files.eric.ed.gov/fulltext/EJ956981.pdf

Nicholls, J. G. (1984). Achievement motivation: Conceptions of ability, subjective experience, task choice, and performance. Psychological Review, 91(3), 328-346. https://doi.org/10.1037/0033-295X.91.3.328

Papadopoulos, K., Paralikas, T., Barouti, M., \& Chronopoulou, E. (2014). Self-esteem, locus of control, and 
various aspects of psychopathology of adults with visual impairments. International Journal of Disability, Development and Education, 61(4), 403-415. https://doi.org/10.1080/1034912X.2014.955785

Pawar, S. (2009). Trusting others, trusting God: Concepts of belief, faith and rationality (Ashgate new critical thinking in religion, theology and Biblical studies). Ashgate Publishing Group.

Petty, R. (2008). Attitudes: Insights from the new implicit measures. Occupational Safety \& Health Guidance Series. CRC Press.

Ray, P. L., Cox, A. P., Jensen, M., Allen, T., Duncan, W., \& Diehl, A. D. (2016). Representing vision and blindness. Journal of Biomedical Semantics, 7(1), 1-12. https://doi.org/10.1186/s13326-016-0058-0

Reese, D., Kim, B., Palak, D., Smith, J., \& Howard, B. (2005). Concept paper: Defining inspiration, the inspiration challenge, and the informal event. WV: Wheeling Jesuit University.

Robinson, B. L., \& Lieberman, L. J. (2004). Effects of visual impairment, gender, and age on self-determination. Journal of Visual Impairment and Blindness, 98(60), 350-366.

Rodriguez, M. A., Wei, X., Xiaoming, W., \& Xinghua, L. (2015). Self-acceptance mediates the relationship between mindfulness and perceived stress. Psychological Reports, 116(2), 513-522. https://doi.org/10.2466/07.PR0.116k19w4

Roodhooft, J. (2002). Leading causes of blindness worldwide. Bulletin of the Belgian Societies of Ophthalmology Publications, 283(3), 19-25.

Salehi, M., Azarbayejani, A., Shafiei, K., Ziaei, T., \& Shayegh, B. (2015). Self-esteem, general and sexual self-concepts in blind people. Journal of Research in Medical Sciences, 20(10), 930-936. https://doi.org/10.4103/1735-1995.172764

Sardegna, J., Shelly, S., Rutzen, A., \& Steidl, S. (2002). The encyclopedia of blindness and vision impairment (2nd ed.). New York, NY: Facts on File, Inc.

Seltzer, L. F. (2008). The path to unconditional self-acceptance: How do you fully accept yourself when you don't know how to? Psychology Today. Retrieved from https://www.psychologytoday.com/blog/evolution-the-self/200809/the-path-unconditional-self-acceptan ce

Sen, A. (1988). Psycho-social integration of the handicapped: A challenge to the society. Delhi, India: Mittal Publ.

Small Groups. (n. d.). Heroes of the faith. Retrieved from https://www.ocbfchurch.org/images/uploads/weekly_devotions/The_Concept_of_Faith.pdf

Smith, M. J., \& In Liehr, P. R. (2014). Middle range theory for nursing (2nd ed.). New York, NY: Springer Publishing Company, Inc.

Snyder, C. R. (2002). Target article: Hope theory: Rainbows in the mind. Psychological Inquiry, 13(4), 249-275. https://doi.org/10.1207/S15327965PLI1304_01

Snyder, C. R., Lopez, S. J., Shorey, H. S., Rand, K. L., \& Feldman, D. B. (2003). Hope theory, measurements, and applications to school psychology. School Psychology Quarterly, 18(2), 122-139. https://doi.org/10.1521/scpq.18.2.122.21854

Stoeber, J. (2003) Self-pity: Exploring the links to personality, control beliefs, and anger. Journal of Personality, 71(2), 183-220. https://doi.org/10.1111/1467-6494.7102004

Szentagotai, A., \& David, D. (2013). Self-acceptance and happiness. In The strength of self-acceptance: Theory, practice and research. New York, NY: Springer New York. https://doi.org/10.1007/978-1-4614-6806-6_8

Thrash, T. M., Moldovan, E. G., Oleynick, V. C., \& Maruskin, L. A. (2014). The psychology of inspiration. Social and Personality Psychology Compass, 8(9), 495-510. https://doi.org/10.1111/spc3.12127

Thrash, T., \& Elliot, A. (2005). Inspiration: Core characteristics, component processes, antecedents, and function. Journal of Personality and Social Psychology, 87(6), 957-973. https://doi.org/10.1037/0022-3514.87.6.957

Todd Royle, M. (2006). The nature and effects of informal accountability for others. Florida State University. Todd Royle, M., \& Hall, A. T. (2012). The relationship between McClelland's theory of needs, feeling 
individually accountable, and informal accountability for others. International Journal of Management and Marketing Research, 5(1), 21-42.

Turner, F. J. (2005). Canadian encyclopedia of social work. Waterloo, ON: Wilfrid Laurier University Press.

University of Surrey. (2001). Accessing hidden and hard-to-reach populations: Snowball research strategies. Retrieved from http://sru.soc.surrey.ac.uk/SRU33.pdf

Walęcka-Matyja, K. (2014). Adolescent personalities and their self-acceptance within complete families, incomplete families, and reconstructed families. Polish Journal of Applied Psychology, 12(1), 59-74. https://doi.org/10.1515/pjap-2015-0004

Weil, A. (2004). Love always. Piedmont, CA: Arthur Weil.

Wnuk M. (2017). In a sample of Polish students' spiritual experiences mediate between hope and religiosity, In: L.F. Cohen, (Eds.), Individual differences, role in recovery, and impact on emotional health (pp. 99-110). New York: Nova Science Publishers.

$\mathrm{Wu}, \mathrm{Z}$. (2014). Family is the most influential factor on happiness in high school students. Health, 6(5), 336-341. https://doi.org/10.4236/health.2014.65049

Yin, R. K. (2011). Qualitative research from start to finish. Spring Street, NY: The Guilford Press.

Ziolko, M. (1991). Counseling parents of children with disabilities: A review of the literature and implications for practice. The Journal of Rehabilitation, 57(2), 29-34. 